\title{
Modern technologies for training future automation engineers
}

\author{
Nikolay Saigushev, Olga Vedeneeva, Elena Kondrashova, Yulia Melekhova, and Anna \\ Vedeneeva
}

Nosov Magnitogorsk State Technical University, 38 Lenina ave., 455000 Magnitogorsk, Russia

\begin{abstract}
Based on the research of special literature, the article considers the project method as a means of training future automation engineers at the University. Industrial modernization encourages the search for new pedagogical approaches in technical universities, which are aimed at individual development of the individual, creative initiative, independence, the formation of universal skills of future automation engineers to solve problems which arise in life - professional career, self-determination, daily life. Project activity stimulates students' educational interest, broadens their minds, develops independent work skills: the ability to reveal and formulate a problem, find and select the necessary information, and use it to solve the tasks set. Using the project method in teaching a foreign language allows future automation engineers to use a foreign language to understand and explain their ideas, understand and accept the ideas of foreign specialists. This is one of the best ways to attract students' attention to language communication and involve them in learning the world around them through a foreign language. The main task for teachers is to raise interest, motivate future automation engineers and involve them in the work environment.
\end{abstract}

\section{Introduction}

The most important thing in modern higher technical education is the upbringing of a truly free personality, the formation of students' ability to think independently, get and use knowledge, consider their decisions carefully, plan actions clearly, cooperate in groups that are different in composition and profile, and be ready for new contacts and cultural ties.

Focusing on the formation of a holistic system of universal educational actions, the federal educational standard of higher education insists on creating such educational conditions under which students within the walls of higher educational institutions will get "experience of independent activity and personal responsibility". Consequently, at the University, the future automation engineer must master modern universal skills, learn to use them in daily life.

Students' independence is the basis of project activity. The results of pedagogical observation and expert assessments draw attention to the fact that modern universities are not ready to realize the didactic potential of project activities in full. It is necessary to modify the learning process, study the preparedness for project activities and its further development.

Recently, the project method has become more widely used in teaching practice in all developed countries. This educational technology is a mixture of different methods, such as: 
research, search, problem-based and creative. It is popular for its positive influence on the creative development of students and their ability to apply the accumulated knowledge to solve problems.

Working on the project develops the independence and activity of future automation engineers, develops creative thinking, and also increases the interest of students in studying the University program. All this, in our opinion, improves the level of knowledge.

All these contradictions determined the relevance of the problem of our research.

\section{Materials and methods}

This paper addresses the problem of teaching German to automation engineers at the University and the specific features of using the project method in German lessons.

The purpose of the work is to analyze the special literature, develop and use the project in the German language classes at the University.

Tasks:

1) to carry out analysis of scientific literature;

2) establish the specifics of the project method based on its characteristics, typology;

3) highlight the stages of the project method in the German language classes;

4) to determine the specifics of implementing the project method in teaching German to automatic engineers at the University.

The obtained results determine its theoretical and practical significance.

The theoretical value of the research is to expand our understanding of the project method.

The practical significance of the research is the possibility of using the materials presented at the University, teaching courses on the theory and methodology of teaching foreign languages.

In our work, we used a set of research methods, including: analysis of scientific literature on the studied problem, definition analysis of dictionary interpretations, classification method, survey, comparative typological method.

Projecting takes a significant place in pedagogy. This issue was studied by researchers Yu. Kh. Zhuravlev, L. Ya. Zorina, V. V. Kraevsky, I. Ya. Lerner and other scientists who believe that pedagogical projecting is an indispensable condition for the realization of the regulatory function of pedagogy and is considered a special type of pedagogical activity nowadays $[1,2,3,4]$.

\section{Results and Discussion}

According to Z. A. Abasov, projecting is a productive thinking activity. Thinking is necessary for planning, executing, and controlling activities [5].

We have analyzed various definitions of the concept of "project" and identified three main meanings:

1) according to G. E. Muraveva, the product of theprojecting activity;

2) $\mathrm{Yu} . \mathrm{V}$. Veselova speaks of the project as an organization of cooperative forms of activity; [6].

3) V. P. Naumov defines the project as one of the concepts of existentialist anthropology

In the first meaning, project is used in the late nineteenth and early twentieth century in the development of engineering and architectural design. The project develops and represents the structure of the projected object, the design of its functioning, the main stages and methods of its manufacture. The project involves drawings and calculations, layouts and other graphic and text materials presented on paper or in electronic form. 
According to A. G. Kulikov, a project is not only a product, but also a means of designing. During its development, the designer implements the requirements for the designed object, creates and compares design solutions, agrees on different plans and levels of development of the object, and so on. In axiological terms, the project carries the potency of the new and the value of the designer.

With this type of activity, a person overcomes the differences between needs and the world, rejects apparently inert matter, "refers to a certain future object", which seeks to bring to life what "has not been yet" [7].

Most scientists believe that "project" is the result of project activity, an object of work made during the projecting process. Many researchers identify the following characteristics of the project: the presence of a common purpose, agreed methods and methods of activity aimed at achieving results, solving a significant problem for the project participants. Most authors describe project activity as a special type of joint activity of students and teachers.

In the dictionary of S. I. Ozhegov, N. Yu. Shvedina, you can see that "project"(in Latin "thrown forward") is defined as a idea, plan; a developed plan of any structure, mechanism, device.

A project (in education) is a set of actions specially organized by a teacher and independently performed by a student to solve a significant problem for people [8].

The term "projecting" is often referred to as technical terminology, but it is also used to refer to the thought process that creates projects of various types.

Method is a didactic category. This is a set of methods, operations for mastering a certain area of practical or theoretical knowledge of any activity. This is the way of knowledge, organization of the process of knowledge, achievement of the set didactic purpose [8].

The project method encourages students to plan and complete tasks, thereby gaining new knowledge.

The project method as a didactic category includes the purpose and the means by which it can be achieved. Any project should be completed with a real practical result, which should be presented in any form.

We understand the project method as a comprehensive learning method that allows future automation engineers to exercise independence in planning, organizing and controlling their activities [8].

Typological features according to E. S. Polat [9]:

1) the method that dominates the project;

2) the nature of project coordination;

3) the nature of contacts;

4) number of project participants;

5) the duration of the project. (Fig. 1)

The project method can be used in a normal group in the form of independent individual, collective work of future automatic engineers for various periods of time, and using modern technological tools.

Besides all ordinary features, there are some specific ones that are typical only for this type of projects $[10,11]$ :

1) use of a foreign language in situations that are as close as possible to the conditions of real communication;

2) the choice of a relevant topic that will be of interest to future machine engineers and is directly related to the conditions under which the project is being implemented;

3 ) selection of language material, types of tasks and sequence of work in accordance with the theme and purpose of the project;

4) visual representation of the result. 


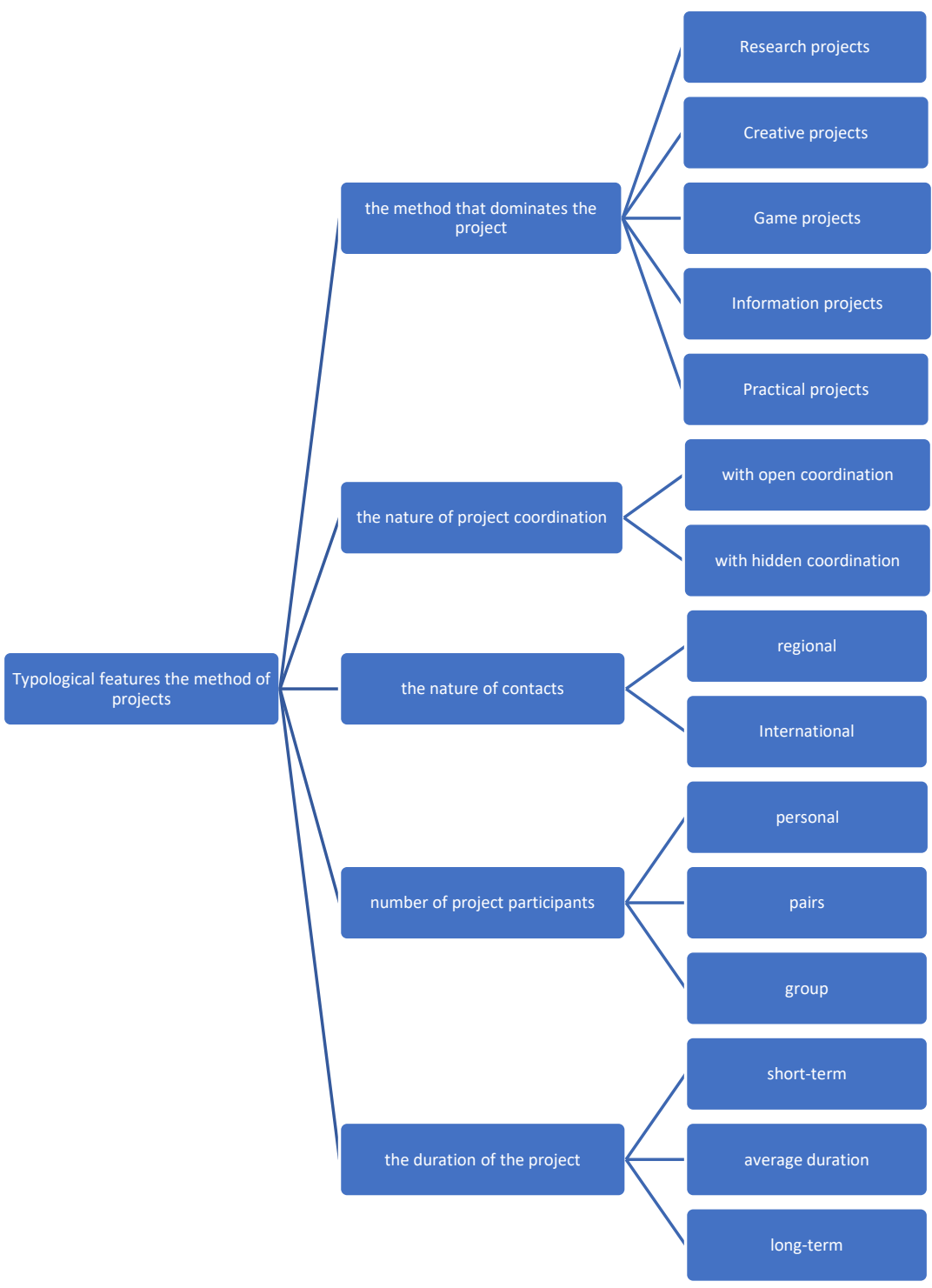

Fig.1. Typological features the method of projects

\section{Conclusions}

Thus, the project method is a purposeful, largely independent activity of future automation engineers, carried out with the help of a teacher, aimed at solving industrial, research and socially significant problems and obtaining a specific result. 


\section{References}

1. V.V. Kraevsky, Metodologiya pedagogiki: novyj etap (2008)

2. I.Ya. Lerner, Didakticheskie osnovy metodov obucheniya (1981)

3. N. Y. Saigushev, O. A. Vedeneeva, Humanitarian and pedagogical research, 2(4) (2018)

4. U. V. Mikhailova, N. Ya. Saigushev, O. A. Vedeneeva, A. A. Tsaran, Journal of Physics: Conference Series, 1015(3) (2018)

5. Z. A. Abasov, Chemistry at school, 6 (2009)

6. O.Gnevek, L.Savva, N.Saigushev, O.Vedeneeva, N.Shepilova, India, 97(21) (2017)

7. A. G. Kulikov, Formirovanie proektnyh umenij studentov starshih kursov v sisteme nepreryvnogo dizajnerskogo obrazovaniya, 13.00.08 (2000)

8. E.G. Azimov, A.N. Shchukin, Novyj slovar' metodicheskih terminov i ponyatij (teoriya i praktika obucheniya yazykam) (2009)

9. E.S. Polat, M.Yu. Buharkina, Sovremennye pedagogicheskie i informacionnye tekhnologii v sisteme obrazovaniya (2010)

10. Z.Yusupova, M.Shakurova, N.Saigushev, O.Vedeneeva, S.Kashina, International review of management and marketing, 6(2) (2016)

11. N. Y. Saigushev, O. A. Vedeneeva, Y. B. Melekhova, A. A. Tsaran, Journal of Physics: Materials Science and Engineering, 843 (2020) 